\title{
ELECTRONIC MODULE DEVELOPMENT ON ALGEBRA STRUCTURE COURSES
}

\author{
Olympia Agustina $^{1 *}$, Farida $^{2}$, Fredi Ganda Putra ${ }^{3}$ \\ ${ }^{1,2,3}$ Department of Mathematics Education, Universitas Islam Negeri Raden Intan Lampung
}

*Corresponding author: olympiaagustina@gmail.com

\begin{tabular}{l}
\hline \hline Article Info \\
\hline Article history: \\
Received: October 12, 2020 \\
Accepted: November 25, \\
2020 \\
Published: November 30, \\
2020
\end{tabular}

Keywords:

Development

Electronic module

Algebra structure courses

\begin{abstract}
This study aims to describe the process of developing an electronic module in the algebraic structure course, and knowing the effectiveness of the electronic module after being tested on mathematics education students. This research was conducted in class $C, 5^{\text {th }}$ semester, majoring in mathematics education at UIN Raden Intan Lampung. The development model used in this research is the Borg and Gall development model. The development of the electronic module was carried out based on the Articulate Studio'13 application. The types of data taken in this study were qualitative data and quantitative data. From the results of due diligence from experts and student responses, the results of the development of an electronic module are very feasible and very interesting. Then, based on the results of the final assessment of student's effectiveness of the product showed a presentation of more than $75 \%$. Based on the research results, it can be concluded that the electronic module in the algebraic structure course is effectively used by mathematics education students.
\end{abstract}

\begin{tabular}{|c|c|}
\hline \multicolumn{2}{|c|}{$\begin{array}{l}\text { PENGEMBANGAN MODUL ELEKTRONIK PADA MATA } \\
\text { KULIAH STRUKTUR ALJABAR }\end{array}$} \\
\hline & ABSTRAK \\
\hline \multirow[t]{2}{*}{ Kata Kunci: } & \multirow{15}{*}{$\begin{array}{l}\text { Penelitian ini bertujuan untuk mendeskripsikan proses } \\
\text { PengembanganModul ElektronikPada Mata Kuliah Struktur } \\
\text { Aljabar, dan mengetahui efektivitas modul elektronik setelah } \\
\text { diujicobakan ke mahasiwa pendidikan matematika. Penelitianin } \\
\text { dilakukan di kelas C semester } 5 \text { jurusan pendidikan matematika } \\
\text { UIN Raden Intan Lampung. Model pengembangan yang digunakan } \\
\text { dalam penelitian ini adalah model pengembangan Borg and Gall } \\
\text { Pengembangan modul elektronik dilakukan menggunakan aplikas } \\
\text { Articulate Studio'13. Jenis data yang diambil dalam penelitian in } \\
\text { berupa data kualitatif dan data kuantitatif. Dari hasil uji kelayakan } \\
\text { dari para ahli dan respon mahasiwa diperoleh hasil pengembangan } \\
\text { modul elektronik yang sangat layak dan sangat menarik. Kemudian } \\
\text { berdasarkan hasil penilaian akhir mahasiswa kefektifan produk } \\
\text { menunjukan presentasi lebih dari } 75 \% \text {. Berdasarkan hasil penelitian } \\
\text { dapat disimpulkan bahwa modul elektronik pada mata kuliah } \\
\text { struktur aljabarefektif digunakan oleh mahasiswa pendidikan } \\
\text { matematika. }\end{array}$} \\
\hline & \\
\hline Pengembangan & \\
\hline $\begin{array}{l}\text { Modul elektronik } \\
\text { Mata }\end{array}$ & \\
\hline & \\
\hline & \\
\hline & \\
\hline & \\
\hline & \\
\hline & \\
\hline & \\
\hline & \\
\hline & \\
\hline & \\
\hline & \\
\hline
\end{tabular}




\section{INTRODUCTION}

Developments in education continue to change significantly over time[1], [2], this changes the mindset of educational actors, from an old and rigid mindset to a more modern one[3], [4]. As the basis of science, mathematics is one of the supporters of the development of science and technology[5]-[7]. The current development of science and technology has various impacts, some of which are negative and positive, among the positive impacts is that it can easily provide learning material without dealing directly with students[8], [9]. Technological development is also beneficial for human life, and has a function in providing motivation for science[10], [11].

The development of technology also affects the development of teaching materials among lecturers and students, one of which is the electronic module. The e-module contains a unit of learning concepts that students can learn independently[20]-[22]. Through the course of algebraic structures, students can find common things from various mathematical systems that they have studied previously[26], and students have the opportunity to gain a deeper understanding of concepts such as inverse[27]-[29]. It plays an important role in algebraic structure because it is full of definitions and theorems [30], [31]. During its development, many mathematical concepts are needed to help solve problems faced in everyday life, as well as to help humans understand and solve social, economic and natural problems [32], [33]. In learning mathematics, a person is trained to think creatively, critically, honestly, and can apply the knowledge of Mathematics in solving problems in everyday life or in other sciences.[32], [34], [35]. Learning media is one of the important components in order to achieve good learning activities [16]-[17]. The use of learning media should be a concern for every lecturer, so that lecturers do not need to learn how to choose and use learning media that can facilitate the achievement of learning objectives [18]-[19].

Education needs to take advantage of advances in gadget technology by presenting electronic modules based on application programs that can be accessed easily [12]. Especially for practitioners of mathematics education. In fact, not many education practitioners have taken advantage of the advancement of ICT, especially the internet, to optimize learning activities [14]. This means that not many education practitioners have developed electronic modules as online learning resources that can be accessed by students [15]. Online learning resources can be designed to present learning modules or electronic modules in mathematics algebraic structures [12]-[13]. Mathematics, as a subject that most people consider difficult, needs to be presented in a creative way and follows the lifestyles of students [39]. One of the programs that can be used to support mathematics learning in an electronic module is the articulate program, the program has the advantage of simple smart brainware with interactive tutorial procedures through templates that can be published offline or online, making it easier for users to format it on a personal web, CD, word processing, and learning Management System (LMS)[23]-[25].

Based on preliminary research, it is known that students in the mathematics education department of UIN Raden Intan Lampung prefer to use electronic media. According to them, using electronic media in this digital age makes them more motivated to learn and has a high enthusiasm for learning, and can make it easier for them to learn from anywhere and anytime. Especially with the development of Smartphone technology among parents, young people, even at an early age. Based on the problems that have been described, the mathematics learning process requires a tool to support learning and renewal in the learning system. With this media, students do not feel bored with the class atmosphere. In addition, there are often additional hours of lessons due to the delivery of material not in accordance with the allocated time, so it is very necessary to have a media 
that can be used by educators without having to hold additional hours. As well as making it easier for them to find more references to the material they are studying, especially in algebraic structure material.

Learning with electronic media is expected to make it easier for educators and students to communicate via internet facilities from anywhere and at any time without being limited by distance, place and time.With the electronic module, students feel that they get more and easier learning references. So that students will get information more quickly and easily, and can apply it to learning activities [36]-[37].

Based on this background, efforts are needed to upgrade learning media in teaching mathematics, especially those that require explanation through interactive media. Based on the problems that have been described, the researchers felt the need to develop an electronic learning module for mathematics material. As for the novelty of this research, the electronic module will be developed using the Articulate Studio'13 software in the algebraic structure course for higher education students majoring in mathematics education.

\section{METHOD}

The type of research used was Research and Development (R\&D) with the Borg and Gall development model. The research was conducted in the mathematics education department of UIN Raden Intan Lampung, the research subject was class C semester 5 with a total sample of 30 students.

The steps for the Borg and Gall development model consist of ten steps, those are: 1) Research and information collecting, 2) planning, 3) develop preliminary form a product, 4) preliminary field testing, 5) main product revision, 6) main field testing, 7) operational product revision, 8) operational field testing, 9) final product revision, 10) dissemination and implementation) [38]. Sampling was done by purposive sampling. The instruments used in this research were test and non-test, the non-test instrument was a questionnaire. The test was used to collect data about the ability of research subjects by means of measurement. At the implementation stage, the experimental class used an electronic module, and the control class used a printed book provided by the school. Data collection was done through posttest.

Borg and Gall's development research procedure can be seen in Figure 1

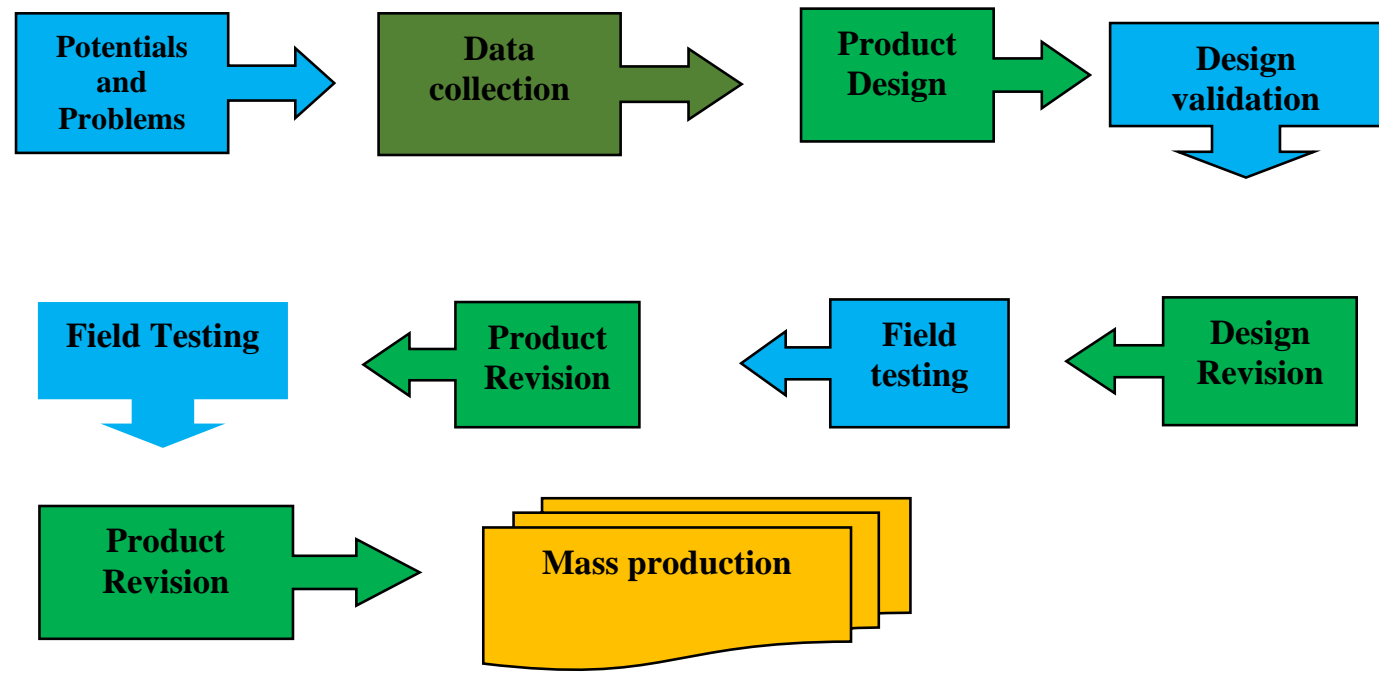

Figure 1. Borg and Gall's Research Procedures

318 Indonesian Journal of Science and Mathematics Education ( I J S M E ) 
Table 1. Procedure for Electronic Module Development in Algebra Structure Courses

\begin{tabular}{|c|c|}
\hline Borg and Gall's Development Model Steps & Development Steps \\
\hline \multicolumn{2}{|c|}{ Research and Informating Collecting } \\
\hline Potential and Problems & $\begin{array}{l}\text { The needs analysis was carried out to see an overview of } \\
\text { the conditions in the field related to the teaching and } \\
\text { learning process of mathematics at UIN Raden Intan } \\
\text { Lampung, then the researchers analyzed the problems. } \\
\text { Needs analysis is done by observation. }\end{array}$ \\
\hline Data Collection & $\begin{array}{l}\text { Aims to find out the problems or obstacles faced in the } \\
\text { field related to Mathematics learning. }\end{array}$ \\
\hline \multicolumn{2}{|r|}{ Planning } \\
\hline Product Design & $\begin{array}{l}\text { Design and develop electronic modules assisted by } \\
\text { Articulate Studio'13 on Group materials. Reference } \\
\text { sources for articulate Studio'13-assisted module } \\
\text { development are obtained from sources that refer to the } \\
\text { material used. }\end{array}$ \\
\hline \multicolumn{2}{|c|}{ Develop Preliminary Form a Product } \\
\hline \multirow[t]{2}{*}{ Design Validation } & $\begin{array}{l}\text { Material experts analyze and see material arranged } \\
\text { according to core competencies and learning objectives. }\end{array}$ \\
\hline & $\begin{array}{l}\text { Media experts analyze and study in terms of media, } \\
\text { choice of words (language) according to target } \\
\text { characteristics, attractiveness of animation-module and } \\
\text { linguistic aspects, presentation of text, images as a whole. }\end{array}$ \\
\hline \multicolumn{2}{|c|}{ Main Product Revision } \\
\hline Design Revision & $\begin{array}{l}\text { Make improvements after validating the material and } \\
\text { media to expert lecturers. }\end{array}$ \\
\hline \multicolumn{2}{|c|}{ Preliminary Field Testing } \\
\hline Lecturee's Response & $\begin{array}{l}\text { The assessment of the lecturer response is intended to } \\
\text { examine the products produced, then the mathematics } \\
\text { department lecturer is asked to be willing to provide } \\
\text { suggestions for improvements about the product. }\end{array}$ \\
\hline Small Group Testing & $\begin{array}{l}\text { Students are asked to see the products produced, then } \\
\text { students are asked to provide comments/responses about } \\
\text { the development of e-modules that have been seen. }\end{array}$ \\
\hline \multicolumn{2}{|c|}{ Operational Product Revision } \\
\hline Field Testing & $\begin{array}{l}\text { The product was tested on a larger number of respondents } \\
\text { with more heterogeneous subjects and the effectiveness } \\
\text { of using electronic modules. }\end{array}$ \\
\hline \multicolumn{2}{|c|}{ Final Product Revision } \\
\hline Final Revision & $\begin{array}{l}\text { Make final repairs and produce a final product that is } \\
\text { ready to use. }\end{array}$ \\
\hline \multicolumn{2}{|c|}{ Dissemination and Implementation } \\
\hline Mass Production & $\begin{array}{l}\text { After the teaching materials have been revised and tested } \\
\text { again, a learning media is produced, namely an electronic } \\
\text { module based on Articulate Studio' } 13 \text { which will then be } \\
\text { published on the Internet or from the social media } \\
\text { application, Blogspot. }\end{array}$ \\
\hline
\end{tabular}

Data analysis was carried out to obtain the feasibility of the revised electronic module. The results obtained are used as material for consideration in improving learning media. The non-test instrument was a questionnaire using a Likert scale. Likert scale is used to measure attitudes, opinions, perceptions of a person or group about social events or symptoms. Calculate the percentage eligibility of each aspect using:

$$
x_{i}=\frac{\sum S}{S_{\max }} \times 100 \%
$$


$S_{\max }=$ Maximum Score

$\sum S=$ Total score

$x_{i} \quad=$ Questionnaire eligibility value for each aspect

In this study, the effectiveness of the electronic module was seen from the student's success indicators (IK) which were taken from the posttest scores. So the use of the product is said to be effective if the IK> $75 \%$. To find out the IK amount, the following formula is used:

$$
\mathrm{IK}=\frac{L}{N} \times 100 \%
$$

IK $=$ Success indicator

$\mathrm{L}=$ The number of students reaching minimum standard

$\mathrm{N}=$ Total students

\section{RESULTS AND DISCUSSION}

At the initial stage, a needs analysis for electronic module development is carried out. Based on field data in preliminary research, it is known that lecturers as teachers use conventional teaching materials (printed module), especially in algebraic structure courses. The weakness of the print module is that it is not able to present some material using simulations, so that students have difficulty understanding abstract material. In addition, students become bored because they were still presented with analogues. This certainly affects students in learning. Students need interesting, innovative and easy to use learning materials to convey messages well, so it is necessary to develop interesting learning materials to support mathematics learning. After analyzing student needs, researchers conducted material analysis. In developing this product, algebraic structure material, adjusted the module material with basic competencies according to the curriculum. In this material, there are many concepts related to everyday life, such as analyzing questions related to Semigroup, Grupoid, Abelian Groups and Groups.

Furthermore, the design of the electronic module in the algebraic structure course uses Articulate Studio'13 which is integrated with Powerpoint. Some of the material content is designed using Coreldraw. Interaction on the module is made with Articulate Engange which includes cover, introduction, simulation and material description. The ability test (evaluation) was made using the Articulate Quiz Maker. After all the content is created, it is then presented into a complete learning module unit with the Articulate Presenter. After being published in the Articulate Presenter, the interactive digital math module is ready to be published in several publication formats. This learning media can be used on a laptop or PC that uses a minimum OS Windows 7. After the e-module has been designed successfully, the next step is the development stage. At the development stage, researchers conducted a media feasibility test by means of product validation. Product validation is carried out after the initial product creation. The validation was carried out by 6 experts, consisting of 3 material experts and 3 media experts. The results of the e-module validation based on Islamic literacy by mathematical material experts show an average score of $68 \%$, and after the revision it shows an average achievement score of $86 \%$ with very feasible criteria in all aspects measured, namely achievement in content feasibility, feasibility presentation, and language assessment. Thus, the overall percentage mean of all aspects increases because it is in accordance with the validator's input and suggestions. The input given is to add diagrams and notation images, sentences are made more passive, and types of exercises are made more varied. After the researcher made revisions according to the suggestions for improvement from the validators, then the three validators reassessed

320 Indonesian Journal of Science and Mathematics Education ( I J S M E ) 
the electronic module product through a questionnaire. Details of the final validation results by material experts on the improved product are presented in Figure 2.

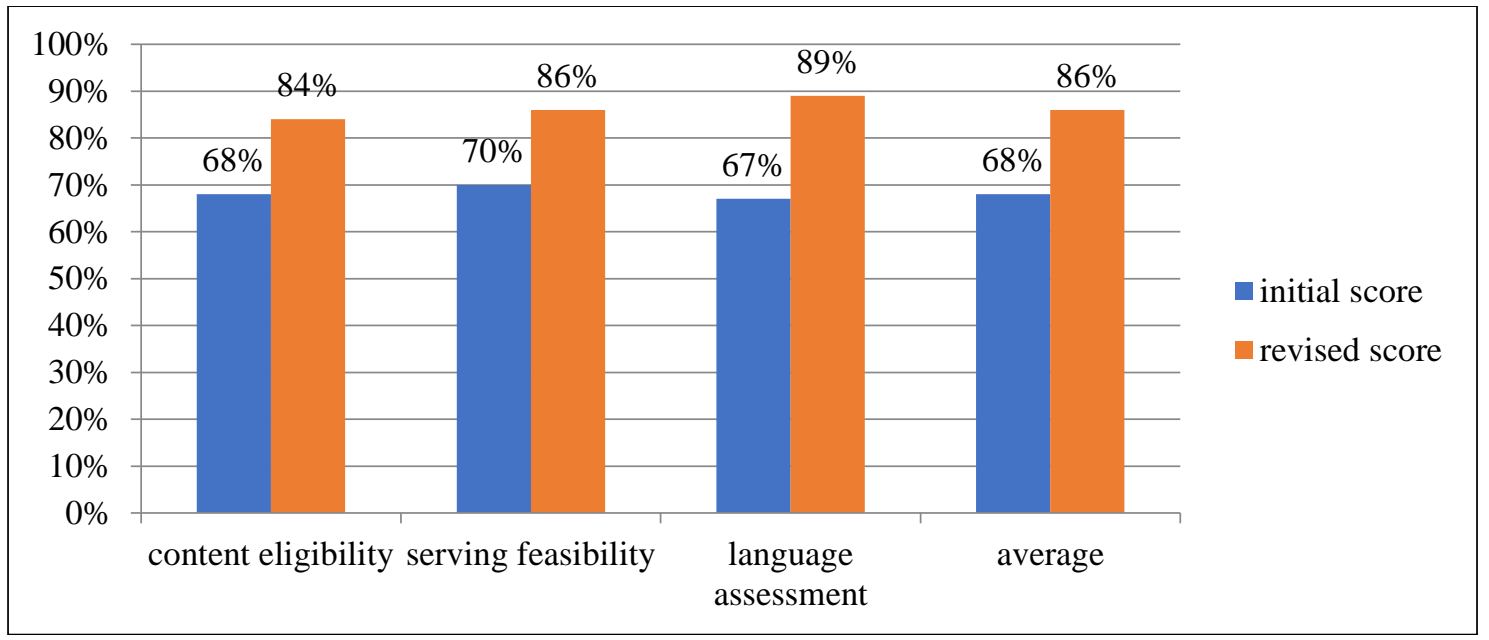

Figure 2. Graph of Validation Test Results by Material Experts

The results of the validation of the electronic module in the algebraic structure course by media experts showed an average score of $74 \%$, and after the revision showed an average score of $93 \%$ with very feasible criteria in all aspects being measured, namely content feasibility, presentation feasibility, and language assessment. . Thus, the overall percentage mean of all aspects increases because it is in accordance with the validator's input and suggestions. The suggestions from the media validator are to improve the words according to official spelling and typography, adjust slide/content transfer from module use to material (symbols), and consistency of symbols or notations. The details of the validation score by media experts are presented in Figure 3.

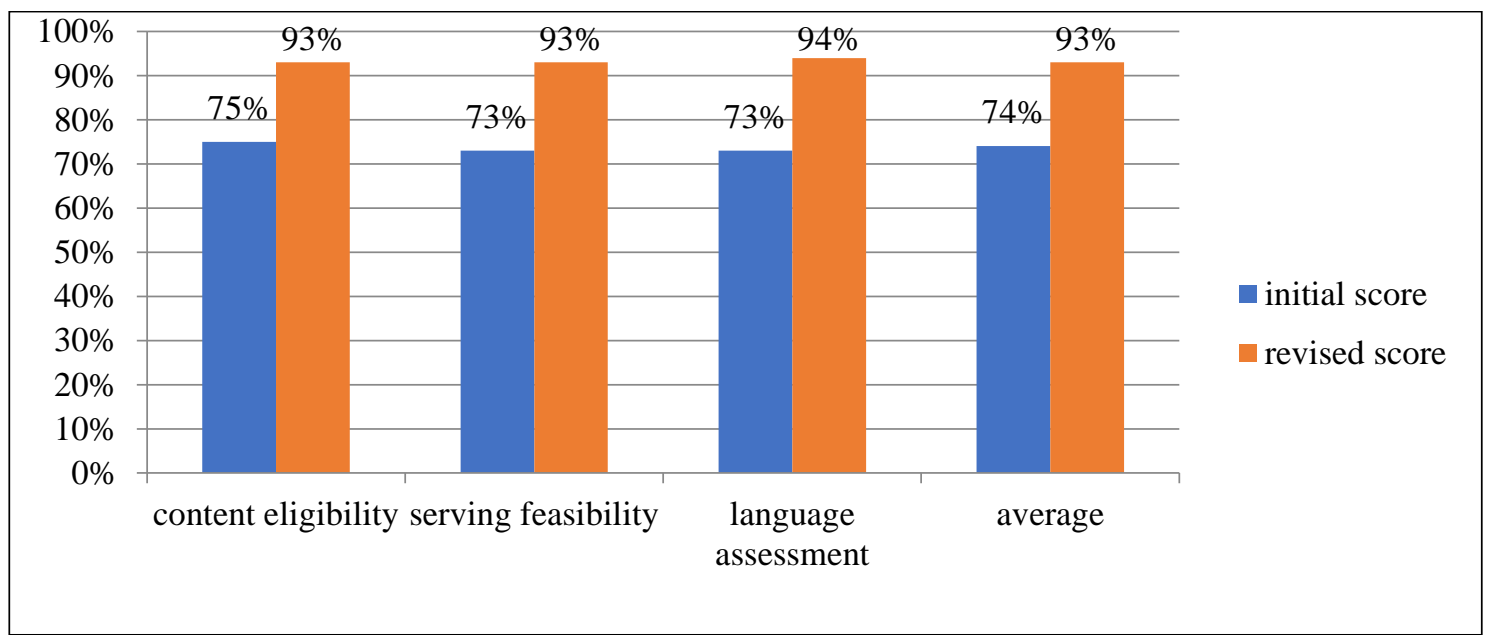

Figure 3. Graph of Validation Test Results by Media Experts

After going through the validation test by experts, the electronic module was tested on mathematics lecturers and students to be able to find out the responses and responses of lecturers and students regarding the electronic module that had been developed. The results of the response from the mathematics lecturer of UIN Raden Intan Lampung show that the percentage of achievement is $87 \%$ with very interesting interpretation of values on all aspects measured, such as media display, use of e-modules, instructions for using emodules, suitability of images, animation, audio, video, simulation., suitability of 
concepts, use of language in the description of the material, and delivery of the material. The percentage details of the lecturers' responses are presented in Figure 4.

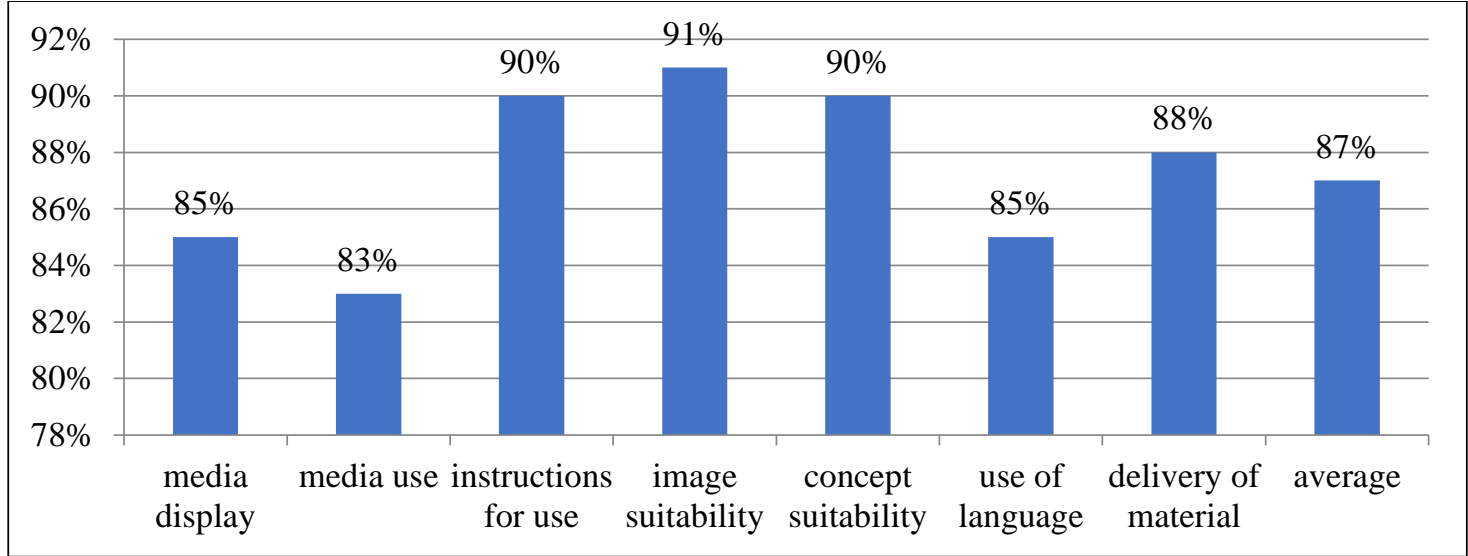

Figure 4. Graph of Lecturer Response Test Results

The results of the small group trial with a total of 10 respondents obtained results with an attractive percentage of $80 \%$ with very attractive criteria in all aspects measured, namely attractiveness and convenience. Furthermore, the results of field trials conducted on 22 respondents got a percentage of $83 \%$ with very attractive criteria in all aspects. Student response to the developed electronic module was very good and very enthusiastic. These results indicate that the electronic module in the algebraic structure course with the Articulate Studio'13 application that has been developed can be very well accepted by students to be used as independent learning material in learning activities in the classroom. Details of the percentage of student responses are presented in Figure 5.

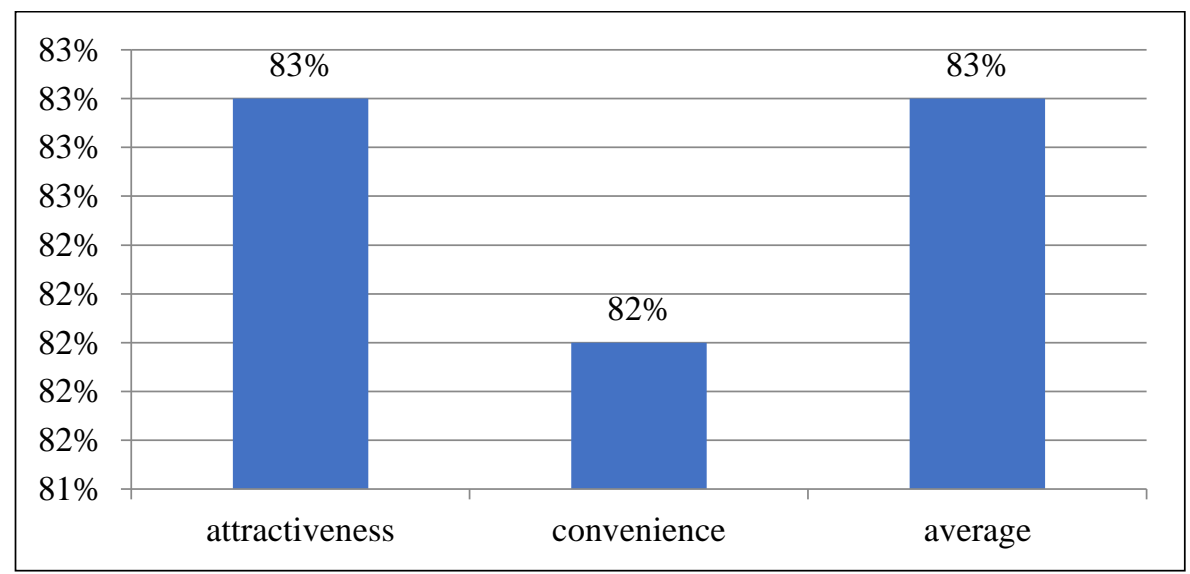

Figure 5. Graph of Student Response Test Results

After receiving the responses of lecturers and students, an evaluation was conducted again as a form of revision of the results of field trials. The suggestions given after the trial are the addition of images and animations with a more attractive and up-to-date appearance. Based on the results of product improvements according to the suggestions, the products are retried, the results of the product trials that have been repaired get responses from lecturers and students who say that this product is good and interesting, so it can be said that this electronic module has reached the final product stage. Table 2 is the final product of the electronic module in the algebraic structure course. 
Tabel 2. Electronic Module of Algebraic Structure Course

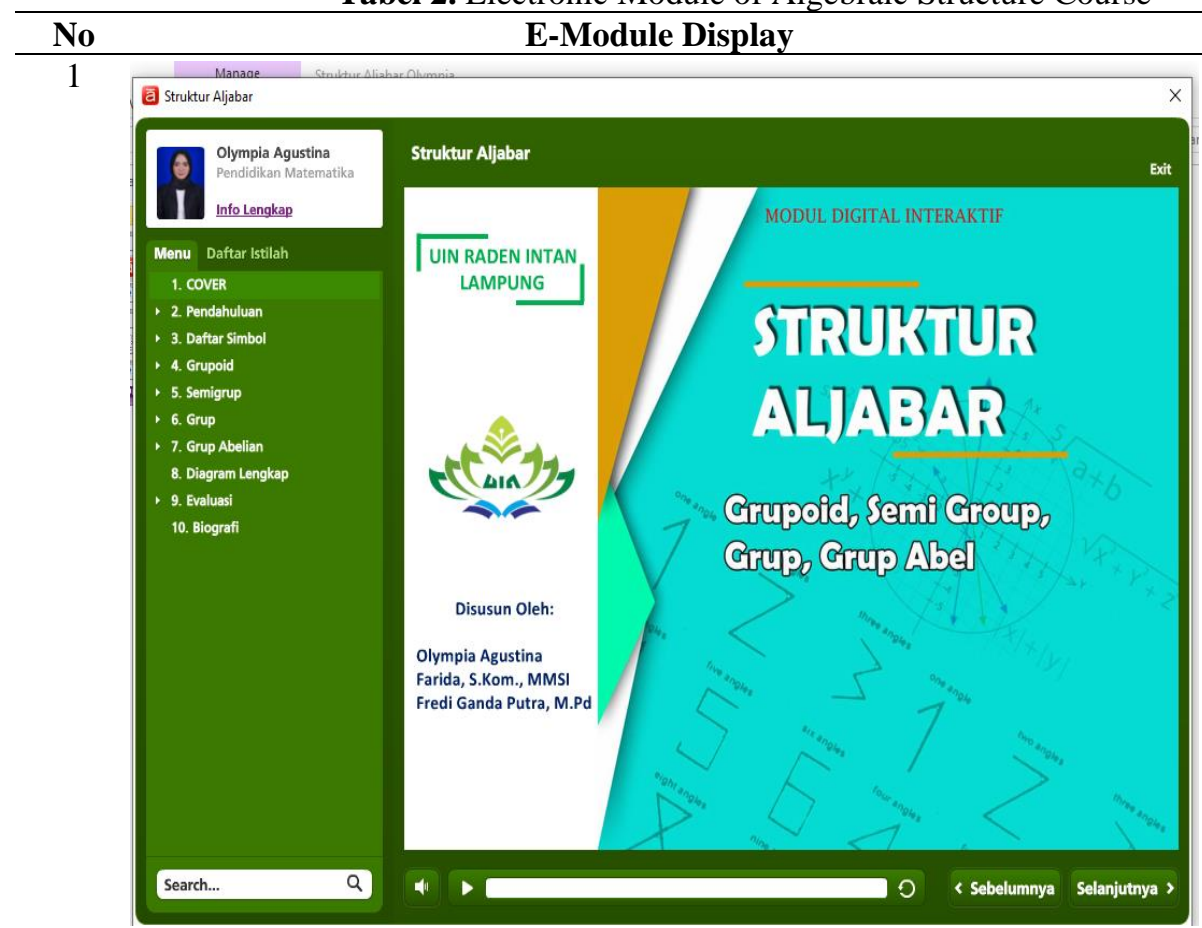

Description

This front page explains the appearance of an attractive

electronic module with algebraic structure courses for students, an electronic module using the Articulate Studio'13

application

The introduction section consists of descriptions, prerequisites, learning objectives, basic competencies in the form of competencies that are expected to be mastered by students after studying the module.

This section consists of several parts of the description, examples of questions and diagrams, in the descriptions presented in the media, namely the meaning groupoids, semigroups, groups and abelian groups and their properties and diagrams. 


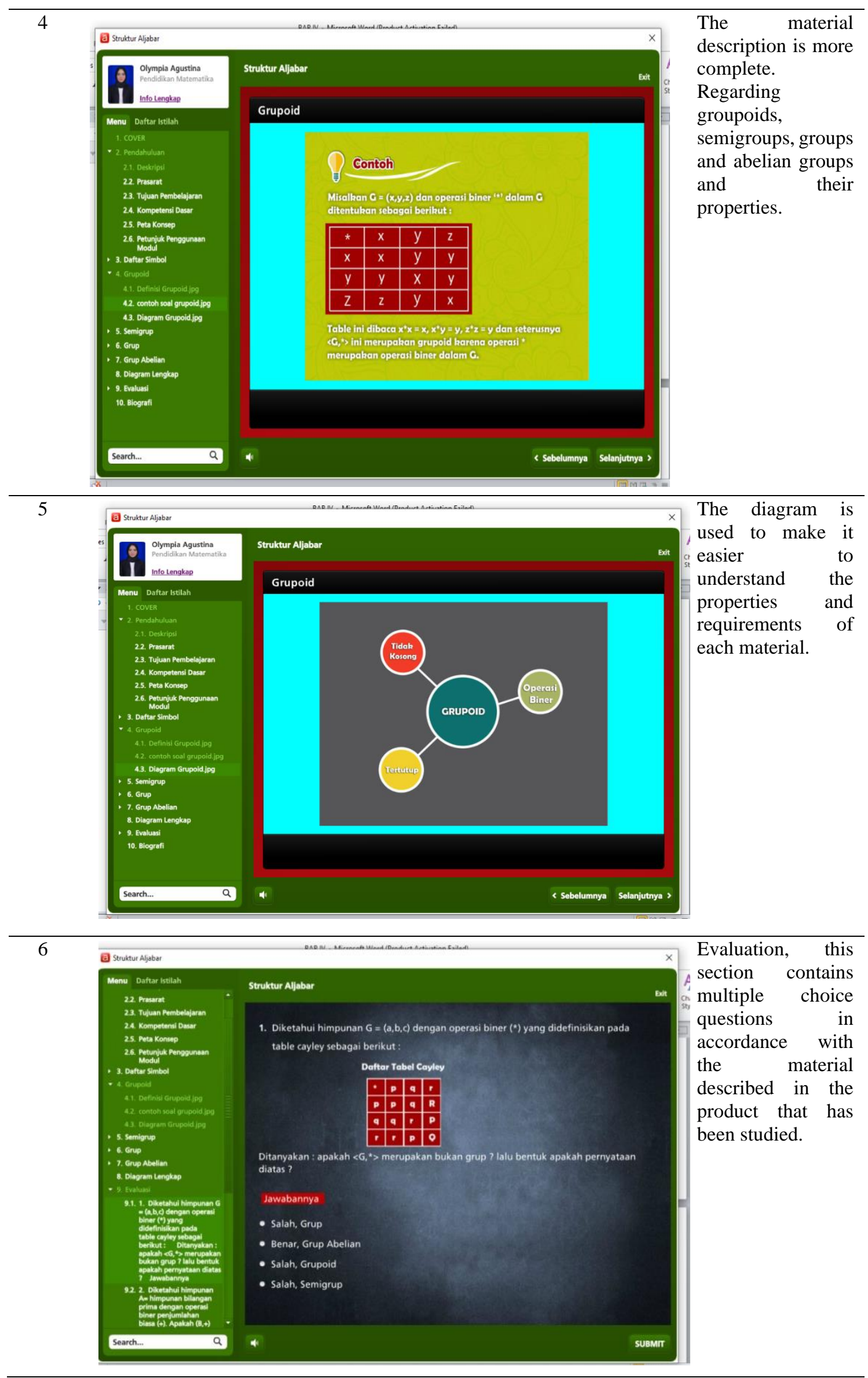

324 Indonesian Journal of Science and Mathematics Education ( I J S M E) 
After obtaining the final product, then the electronic module is used in mathematics learning. Posttest was carried out and the learning outcomes were obtained. Based on the calculations that have been made, the n-gain average in the experimental class is 0.7270 and in the control class is 0.5805 . From the average n-gain obtained, the experimental class has a higher average $n$-gain than the control class. The results of $t_{\text {count }}$ in the experimental class using the Articulate Studio'13 electronic module on Grupoid, Semigroup, Group, and Abelian Group material in the teaching and learning process and in control classes that do not use the Articulate Studio'13 electronic module on Grupoid, Semigroup, Abelian Group and Group material shows the results oft $\mathrm{count}_{\mathrm{is}} 5.5933$ and the value of $\mathrm{t}_{\text {table }}$ is 2.0423 . Then, according to the criteria that if $t_{\text {count }}>t_{\text {table, then }} \mathrm{H}_{1}$ is accepted. So, we can take the conclusions from the t-test results that there is an influence on the learning process using the Articulate Studio'13 electronic module on the material of Grupoid, Semigroup, Group, and Abelian Group at UIN Raden Intan Lampung. With the application of the electronic module in the algebraic structure course there is an influence to improve student learning outcomes. According to the results of the student's final assessment of the effectiveness of the product, the presentation was more than $75 \%$. Based on the research results, it can be concluded that the electronic module in the algebraic structure course is effectively used by mathematics education students.

\section{CONCLUSION}

Based on the results of research and development that has been carried out by researchers, it can be concluded that the following electronic module uses Articulate Studio'13 in mathematics learning in the subject of algebraic structure of the material of Grupoid, Semigroup, Group and Abelian Group, according to experts, this e-module is stated "Very feasible", and based on student responses to this electronic module, students give an assessment with the criteria "Very Interesting", in small-scale trials and large-scale trials. The percentage of product effectiveness can be seen from the value of student learning outcomes with indicators of success $>75 \%$, with an assessment result of $76.67 \%$. Based on the results of the implementation, this e-module is also known to have an effect

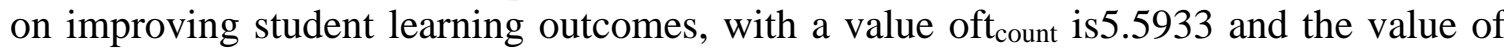
$\mathrm{t}_{\text {table }}$ is 2.0423 . Thus, the product is declared effective in use in learning activities.

\section{REFERENCES}

[1] F. E. E. Kusuma, M. B. Setyawan, Dan I. A. Zulkarnain, "Penerapan Teknologi Augmented Reality Berbasis Android Sebagai Media Pembelajaran Pengenalan Aksara Jawa Di Sdn 1 Sidorejo Ponorogo," Komputek, Vol. 3, No. 1, 2019.

[2] S. Priatmoko, "Memperkuat Eksistensi Pendidikan Islam Di Era 4.0," Talim J. Studi Pendidik. Islam, Vol. 1, No. 2, Hlm. 221-239, 2018.

[3] A. Asrin Dan H. A. H. Anwar, "Perubahan Pola Pendidikan Anak Usia Sd Pada Keluarga Nelayan Di Desa Bakealu Kecamatan Wakorumba Selatan Kabupaten Muna (1998-2016)," J. Penelit. Pendidik. Sej. Uho, Vol. 2, No. 3, 2019.

[4] O. Kurniaman Dan E. Noviana, "Penerapan Kurikulum 2013 Dalam Meningkatkan Keterampilan, Sikap, Dan Pengetahuan," Prim. J. Pendidik. Guru Sekol. Dasar, Vol. 6, No. 2, Hlm. 389-396, 2017.

[5] N. Baeti, "Analisis Kemampuan Berpikir Kreatif Siswa Dalam Pemecahan Masalah Matematika Di Smp."

[6] S. A. Prawiro Dan A. H. Irawan, "Perancangan Media Pembelajaran Interaktif Ilmu Pengetahuan Alam Untuk Siswa Kelas 4 Sd Dengan Metode Learning The Actual Object," J. Sains Dan Seni Its, Vol. 1, No. 1, Hlm. F28-F33, 2012. 
[7] M. D. Siagian, "Kemampuan Koneksi Matematik Dalam Pembelajaran Matematika," Mes J. Math. Educ. Sci., Vol. 2, No. 1, 2016.

[8] A. Adnan, D. Komarudin, Dan A. Upe, Pengaruh Perkembangan Teknologi Smartphone Terhadap Moralitas Mahasiswa. Lp2m Uin Bandung, 2017.

[9] A. H. Subarjo, "Pemanfaatan Internet Dalam Mata Kuliah Kewarganegaraan," Retii, 2016.

[10] I. K. Sudarsana, "Peningkatan Mutu Pendidikan Luar Sekolah Dalam Upayapembangunan Sumber Daya Manusia,” J. Penjaminan Mutu, Vol. 1, No. 1, Hlm. 1-14, 2016.

[11] T. Tafonao, "Peranan Media Pembelajaran Dalam Meningkatkan Minat Belajar Mahasiswa," J. Komun. Pendidik., Vol. 2, No. 2, Hlm. 103-114, 2018.

[12] R. Firdaos, "Orientasi Pedagogik Dan Perubahan Sosial Budaya Terhadap Kemajuan Ilmu Pendidikan Dan Teknologi," Al-Tadzkiyyah J. Pendidik. Islam, Vol. 6, No. 1, Hlm. 106-117, 2015.

[13] Z. Mustakim, "Pendidikan Islam, Globalisasi Teknologi Informasi, Dan Moralitas Bangsa (Eksistensi Pendidikan Islam Di Era Globalisasi Teknologi Informasi)," Edukasia Islam., Vol. 11, No. 1, Hlm. 89690, 2013.

[14] E. Syahmaidi, "Pengembangan Media E-Learning Mata Pelajaran Teknologi Informasi Dan Komunikasi Untuk Kelas Xi Sma,” J. Ipteks Terap., Vol. 9, No. 1, 2017.

[15] M. Yazdi, "E-Learning Sebagai Media Pembelajaran Interaktifberbasis Teknologi Informasi," Dalam Foristek: Forum Teknik Elektro Dan Teknologi Informasi, 2012, Vol. 2, No. 1

[16] A. A. Azis, "Pengembangan Media E-Learning Berbasis Lms Moodle Pada Matakuliah Anatomi Fisiologi Manusia," J. Pendidik. Biol., Vol. 7, No. 1, Hlm. 18, 2017.

[17] A. Handayanto, R. Rasiman, S. Supandi, Dan L. Ariyanto, "Pembelajaran ELearning Menggunakan Moodle Pada Matakuliah Metode Numerik," J. Inform. Upgris, Vol. 1, No. 1 Juni, 2015.

[18] S. Rizal Dan B. Walidain, "Pembuatan Media Pembelajaran E-Learning Berbasis Moodle Pada Matakuliah Pengantar Aplikasi Komputer Universitas Serambi Mekkah," J. Ilm. Didakt. Media Ilm. Pendidik. Dan Pengajaran, Vol. 19, No. 2, 2019.

[19] S. Fatmawati, "Efektivitas Forum Diskusi Pada E-Learning Berbasis Moodle Untuk Meningkatkan Partisipasi Belajar," Refleksi Edukatika J. Ilm. Kependidikan, Vol. 9, No. 2, 2019.

[20] M. Fausih, "Pengembangan Media E-Modul Mata Pelajaran Produktif Pokok Bahasan 'Instalasi Jaringan Lan (Local Area Network)' Untuk Siswa Kelas Xi Jurusan Teknik Komputer Jaringan Di Smk Nengeri 1 Labang Bangkalan Madura," J. Mhs. Teknol. Pendidik., Vol. 5, No. 3, 2015.

[21] E. A. Simarmata, G. S. Santyadiputra, M. C. St, Dan D. G. H. Divayana, "Pengembangan E-Modul Berbasis Model Pembelajaran Project Based Learning Pada Mata Pelajaran Pemrograman Desktop Kelas Xi Rekayasa Perangkat Lunak Di Smk Negeri 2 Tabanan," Karmapati Kumpul. Artik. Mhs. Pendidik. Tek. Inform., Vol. 6, No. 2017.

[22] S. Sunismi Dan A. H. Fathani, "Pengembangan E-Module Kalkulus I Sebagai Panduan Mahasiswa Untuk Mengoptimalkan Individual Learning," J. Pendidik. Mat. Jpm, Vol. 1, No. 2, 2018.

326 Indonesian Journal of Science and Mathematics Education 
[23] S. Donny Setiawan, "Plagiasi Pengembangan Media Pembelajaran Berbasis Articulate Studio" 13 Mata Kuliah Perkembangan Motorik," Bravo" J., Vol. 6, No. 4, 2019.

[24] F. A. Ghozali Dan P. W. Rusimamto, "Pengembangan Media Pembelajaran Berbasis Articulate Studio'13 Kompetensi Dasar Arsitektur Dan Prinsip Kerja Fungsi Setiap Blok Plc Di Smk Negeri 1 Sampang," J. Pendidik. Tek. Elektro, Vol. 5, No. 1, 2016.

[25] D. Setiawan, "Model Pembelajaran Kooperatif Tipe Jigsaw Berbasis Articulate Untuk Meningkatkan Keterampilan Sosial Siswa," Dalam The 4th Iceta International Conference On Education.

[26] N. A. Lestari, "Implementasi Pembelajaran Matematika Model Pace Untuk Meningkatkan Kemampuan Pembuktian Matematis Pada Mata Kuliah Aljabar Abstrak Mahasiswa S1 Pendidikan Matematika Fkip Universitas Bengkulu," J. Equ. Teori Dan Penelit. Pendidik. Mat., Vol. 1, No. 1, Hlm. 81-94, 2018.

[27] R. Y. Gazali, "Penerapan Model Pembelajaran Kooperatif Tipe Ts-Ts Pada Mata Kuliah Struktur Aljabar," Math Didact. J. Pendidik. Mat., Vol. 3, No. 1, Hlm. 4354, 2017.

[28] E. Herlina, "Meningkatkan Advanced Mathematical Thinking Mahasiswa," Infin. J., Vol. 4, No. 1, 2015.

[29] A. S. Pramasdyahsari Dan M. R. Rubowo, "Pemahaman Konsep Grup Mahasiswa Calon Guru Matematika Dengan Kemampuan Matematika Tinggi," Prism. J. Pendidik. Dan Ris. Mat., Vol. 2, No. 2, Hlm. 71-84, 2020.

[30] I. M. Arnawa, "Mengembangkan Kemampuan Mahasiswa Dalam Memvalidasi Bukti Pada Aljabar Abstrak Melalui Pembelajaran Berdasarkan Teori Apos," J. Mat. Dan Sains, Vol. 14, No. 2, 2010.

[31] J. Jamilah Dan S. Fadillah, "Penggunaan Bahan Ajar Struktur Aljabar Untuk Meningkatkan Kemampuan Pembuktian Matematis Pada Mahasiswa Ikip Pgri Pontianak," J. Pendidik. Mat. Dan Ipa, Vol. 8, No. 2, 2017.

[32] B. S. Anggoro, "Pengembangan Modul Matematika Dengan Strategi Problem Solvin Guntuk Mengukur Tingkat Kemampuan Berpikir Kreatif Matematis Siswa," Al-Jabar J. Pendidik. Mat., Vol. 6, No. 2, 2015.

[33] N. Kholisiyah Dan D. I. Yuanita, "Implementasi Pembelajaran Kontekstual Dengan Strategi React (Relating, Experiencing, Applying, Cooperating, Dan Tranferring)," J. Intelekt. J. Pendidik. Dan Studi Keislam., Vol. 8, No. 2, Hlm. 195204, 2018.

[34] T. P. Pratiwi, "Strategi Peningkatan Pendapatan Asli Daerah, Investasi Dan Pertumbuhan Ekonomi Kota Semarang Melalui Mice (Meeting, Incentive, Convention Dan Exhibition)," Econ. Dev. Anal. J., Vol. 3, No. 1, 2014.

[35] W. Wiliawanto, M. Bernard, P. Akbar, Dan A. I. Sugandi, "Penerapan Strategi Pembelajaran Aktif Question Student Have Untuk Meningkatkan Kemampuan Berpikir Kritis Matematik Siswa Smk,” J. Cendekia J. Pendidik. Mat., Vol. 3, No. $1,2019$.

[36] M. Muzannur, "Pengembangan Modul Digital Interaktif Berbasis Articulate Studio'13 Pada Mata Pelajaran Fisika Kelas X Materi Gerak Melingkar," Uin Raden Intan Lampung, 2017.

[37] F. Farida, S. Suherman, Dan S. Zulfikar, "Peningkatan Kemampuan Pemahaman Konsep Himpunan Melalui Pembelajaran Matematika Dengan Media Articulate Studio'13," Jshp J. Sos. Hum. Dan Pendidik., Vol. 3, No, 2019. 
[38] C. Utama Dan A. Mashfufah, "Implementasi Media Pembelajaran Articulate Studio Untuk Meningkatkan Hasil Belajar Siswa," J. Pena Sains, Vol. 3, No. 1, , 2016.

[39] R. Maskur, N. Nofrizal, Dan M. Syazali, "Pengembangan Media Pembelajaran Matematika Dengan Macromedia Flash," Al-Jabar J. Pendidik. Mat., Vol. 8, No. 2, 2017.

[40] I. Irwandani, S. Latifah, A. Asyhari, M. Muzannur, Dan W. Widayanti, "Modul Digital Interaktif Berbasis Articulate Studio'13: Pengembangan Pada Materi Gerak Melingkar Kelas X,” J. Ilm. Pendidik. Fis. Al-Biruni, Vol. 6, No. 2, 2017. 